\title{
Atmospheric circulation conditions during winter warm spells in Central Europe
}

\author{
Arkadiusz M. Tomczyk ${ }^{1}$ (D) Agnieszka Sulikowska $^{2}$ Ewa Bednorz $^{1}$. \\ Marek Półrolniczak ${ }^{1}$
}

Received: 30 April 2018 / Accepted: 14 May 2019 / Published online: 18 May 2019

(c) The Author(s) 2019

\begin{abstract}
The objective of the paper was to characterise the temporal and spatial variability of winter warm spells in Central Europe in the years 1966/1967-2015/2016 and to determine the circulation conditions of their occurrence. The applied data were obtained from the Polish Institute of Meteorology and Water Management, Deutscher Wetterdienst and the National Centre for Environmental Prediction/National Centre for Atmospheric Research. A warm spell was defined as a sequence of at least three warm days, i.e. when the maximum air temperature is higher than the 95th percentile of the probability density function designated from observation. The research has proven that over the study period the air temperature increased in the winter season in Central Europe and this translated into an increase in the number of warm days. An average of 3-5 warm spells was recorded per 10 years. The most numerous warm spells occurred during three winter seasons, i.e. 1989/1990, $2006 / 2007$ and 2015/2016. The occurrence of warm spells was related to positive anomalies of geopotential heights over the study area in the cross section of the entire troposphere. Maximum anomalies appeared at $250 \mathrm{hPa}$ geopotential height, and they developed on average 9 days before the commencement of warm spells over the study area.
\end{abstract}

Keywords Winter warm spells $\cdot$ Circulation conditions $\cdot$ Geopotential anomalies $\cdot$ Central Europe

\section{Introduction}

Climatic changes observed in recent decades have mainly been expressed as a global increase in mean air temperature of approximately $0.85{ }^{\circ} \mathrm{C}$, over the period $1880-2012$. Each of the last three decades has been warmer than the previous one, and the 30-year period 1983-2012 was probably the warmest period in the last 1400 years in the northern

Arkadiusz M. Tomczyk

atomczyk@amu.edu.pl

1 Department of Climatology, Institute of Physical Geography and Environmental Planning, Adam Mickiewicz University in Poznań, B. Krygowskiego 10, 61-680 Poznań, Poland

2 Department of Climatology, Institute of Geography and Spatial Management, Jagiellonian University in Kraków, Kraków, Poland 
hemisphere (IPCC 2013). Apart from the observed increase in air temperature, climate changes, potentially resulting in unfavourable effects in many areas of life, are also manifested in higher frequency, intensity and duration of extreme climatic events in many regions of Europe and around the globe (Katz and Brown 1992; Menzel et al. 2011; Shevchenko et al. 2014; Chen et al. 2017; Diffenbaugh et al. 2017; Ummenhofer and Meehl 2017).

An increase in air temperature manifests as an increase in the frequency of heat waves in summer and warm spells in winter. According to Francis and Vavrus (2012), these anomalous periods should be more persistent due to an increased amplitude of Rossby waves and their slower progression eastward. Such modifications in global circulation are an effect of the observed enhanced warming at high northern latitudes relative to mid-latitudes (Arctic amplification) and the relaxation of poleward 1000-to-500 hPa thickness gradients. Weakening zonal winds and slowing planetary waves translate into more persistent weather patterns at mid-latitudes, which are often extreme and are associated with upper tropospheric pressure and air flow patterns. Qian et al. (2016) also connected persistent extreme surface weather episodes with signals in the middle and higher troposphere. They proved that anomalies of geopotential heights at the $300 \mathrm{hPa}$ level are strongly related to persistent periods of surface anomalous temperature in China. These geopotential height anomalies appear prior to the observed surface temperature extremes and can therefore be considered as prognostic signals of an approaching extreme weather. Furthermore, they postulated that an increase in frequency of heat waves is directly responsible for the growing frequencies of macroscale quasi-stationary centres with positive anomalies of geopotential heights in the upper troposphere. Strong patterns of geopotential heights anomalies in the upper troposphere were also recorded to precede the occurrence of surface temperature extremes (cold spells) in north-east China (Qian and Jiang 2014) and in research concerning extreme heat waves in east China (Chen et al. 2017).

Wibig (2007) related periods of mid-winter warm spells in central Poland to macroscale circulation indices. She proved that positive temperature anomalies were positively correlated with the Zonal Circulation Index, and with the East Atlantic and North Atlantic Oscillation circulation types. The determined relationships, however, account for a maximum of $25 \%$ of the variability of the events. She postulated that the composite method, which makes it possible to identify synoptic situations that favour the occurrence and maintenance of strong positive thermal anomalies, and which is based on the analysis of baric centres located near the study area, provides more accurate results. Synoptic situations responsible for the occurrence of warm spells in winter are related to the advection of relatively warm air from over the Atlantic as a result of the simultaneous occurrence of a high-pressure system over South Europe and a centre of low pressure over North Europe.

In the analysis of extreme weather events, the choice of the criterion for evaluating and selecting them is crucially important. Beniston and Stephenson (2004) mention the following three basic criteria for designating extreme events: the frequency, the intensity and the effects of their occurrence. According to the first criterion, extreme phenomena include those that occur extremely rarely (in time and/or space). The second criterion is met by phenomena that are not necessarily rare, but occur with high intensity (e.g. storms, tornados, hurricanes). The third category of phenomena causes considerable material losses. According to the above, warm spells in winter can be included among extreme events particularly due to the first criterion, i.e. rare occurrence, but also due to the related economic losses and threat to the natural environment, animals and people. Rapid warmings in winter causing thaws lead to thaw floods and negatively affect transport, industry and tourism (Shabbar and Bonsal 2003; Wibig 2007). In agriculture and horticulture, changes in air 
temperature in winter and early spring, which determine the period of rest and development of plant organisms, are particularly important (Chmielewski et al. 2004). Research on autumn and winter warm spells shows their effect on the phenological cycle of many species, manifesting as untypical, prolonged or premature flowering of plants in the warm period, particularly at the end of winter (Luterbacher et al. 2007; Menzel et al. 2011).

The variability of the number of days in winter warm spells in the period 1976-99 for Region VI of the WMO (Europe and Middle East: Lebanon, Syria, Jordan and Israel) was analysed in the framework of the European Climate Assessment project (ECA) (Klein Tank et al. 2002). According to the authors, winter warming in the period $\left(0.47{ }^{\circ} \mathrm{C} / 10\right.$ years $)$ caused a higher number of days with warm spells (on average 3 days/decade) in almost all 168 analysed stations. Perkins et al. (2012) evidenced a positive trend of warm spells during the year on the global scale. Additionally, an increase in the number of hot days, as well as an increase in the highest intensity and duration of heat waves in the summer season, was determined both globally and in particular regions of the world and Europe (DellaMarta et al. 2007; Wibig et al. 2009; Bielec-Bąkowska and Piotrowicz 2013; Peterson et al. 2013).

Considering the growing frequency of warm weather episodes in the times of contemporary climatic changes, as well as the high importance of winter warm spells in many areas of the economy, it seems justified to adopt the following research objectives:

1. Analysis of temporal and spatial variability of winter warm spells in Central Europe in the years 1966/67-2015/16;

2. Determination of the circulation conditions of winter warm spells through analysis of baric conditions in the troposphere during their occurrence and on preceding days;

3. Identification of the areas of maximum geopotential height anomalies in the upper troposphere preceding the upcoming winter warm spells.

\section{Data and methods}

The basis for the paper were maximum air temperature values $\left(T_{\max }\right)$ for 40 stations in Germany and Poland from the period 1966-2016 (in two stations, Kassel and Elblag, the disclosed data covered the multi-annual period 1966-2013) (Fig. 1). The data were obtained from the Polish Institute of Meteorology and Water Management and from the Deutscher Wetterdienst.

In spite of wide interest of climatologists in extreme thermal events, there are no universal and commonly accepted criteria for determining them (Perkins 2015). Warm spells are usually defined as a continuous sequence of several days when air temperature is higher than a certain threshold value. Their minimum duration is different depending on the objective of a given paper, but in climatological research it is frequently adopted as 3 days (Nairn and Fawcett 2011; Perkins 2015). Thresholds above which air temperature is considered extreme can be determined arbitrarily or relatively. In areas with variable climatic conditions, the latter way is more useful, and the application of high percentiles is the most popular and recommended by IPCC (2013). The description of selected criteria and methods for designating warm spells and their comparison can be found among others in publications by Perkins and Alexander (2013), Smith et al. (2013) and You et al. (2017). According to the results of the aforementioned studies, the 


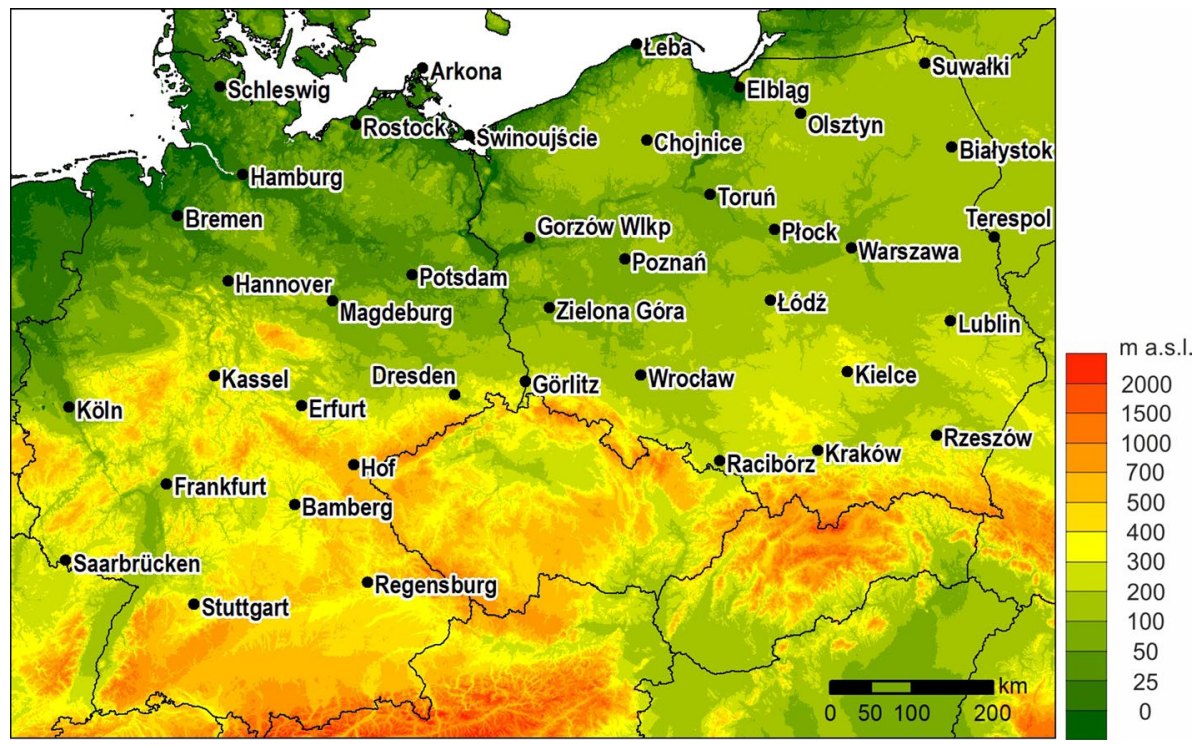

Fig. 1 Location of meteorological stations used in the study

selection of the criterion is of key importance, because results obtained by means of different methods can differ significantly, or even be opposite.

In this paper, a warm spell is defined as a continuous sequence of at least three warm days when the maximum air temperature is higher than the 95th percentile of the probability density function determined from observation. This relatively rigorous criterion permitted the identification of only major warm spells that can have considerable effects on the natural environment and human economy. Percentiles were calculated for each calendar day by the method of a 15-day window centred on a given day, so that they reflect average thermal conditions specific to a given part of the season (Fischer and Schär 2010; Perkins and Alexander 2013). Percentiles were determined from the reference period 1981-2010 in order to provide comparability of results with other studies.

The frequency of occurrence of warm days and warm spells was determined, as well as the duration of the latter. Tendencies of changes in $T_{\max }$ were assessed by means of linear regression, and significance of trends was verified by a Student's t test. Trends of warm days were determined by means of a nonparametric Mann-Kendall test used for the analysis of data with distribution diverting from normal, and their statistical significance was assessed by Sen's method at a level of $\alpha=0.05$. Tendencies of changes in warm spells were not determined, because of the insufficient number of cases.

For the purpose of determining baric conditions during warm spells and on days preceding their occurrence, daily values of atmospheric pressure at sea level and heights of isobaric surfaces (at 1000, 925, 850, 700, 600, 500, 400, 300, 250, 200, 150, 100 and $70 \mathrm{hPa}$ ) were used, as well as air temperatures at the aforementioned levels. Data for nodes of the geographic grid $2.5^{\circ} \times 2.5^{\circ}$ for the area $25-75^{\circ} \mathrm{N}$ and $35^{\circ} \mathrm{W}-65^{\circ} \mathrm{E}$ were obtained from the collection of the National Centre for Environmental Prediction/ National Centre for Atmospheric Research (NCEP/NCAR) Reanalysis (Kalnay et al. 1996) available in the archives of NOAA ESRL PSD (Earth System Research Laboratory Physical Science Division). 
First, based on the aforementioned data, cross sections through the troposphere were designated (from level $1000 \mathrm{hPa}$ to level $70 \mathrm{hPa}$ ) with anomalies of geopotential heights and air temperature along three meridians $\left(10,15,20^{\circ} \mathrm{E}\right)$ and one parallel $\left(52.5^{\circ} \mathrm{N}\right)$. Then, average maps of sea level pressure (SLP) and isobaric surface height $250 \mathrm{hPa}(\mathrm{z} 250)$ were prepared, as well as maps of anomalies of the above parameters and air temperature on isobaric surface $850 \mathrm{hPa}$ (T850) for all warm spells. Moreover, maps of SLP and z250 anomalies averaged for all warm spells were prepared for days preceding their occurrence. At the next stage, routes of progression of centres of z250 anomalies were determined for each warm spell for days preceding their occurrence and for the first days of the warm spells. All anomalies were calculated as a difference between a given day's average value for sea level pressure, isobaric surface heights and the air temperature at such levels on the one hand, and, on the other, the average value of the aforementioned elements on a given day in the studied multi-annual period. All analyses covered only warm spells that occurred in at least $25 \%$ of the analysed stations. The objective of the adopted assumption was the elimination of single cases of spells with a local range.

\section{Results}

Mean $T_{\max }$ in winter in the analysed stations varied from $-1.0{ }^{\circ} \mathrm{C}$ in Suwałki to $5.9{ }^{\circ} \mathrm{C}$ in Köln. The spatial distribution shows its negative gradient from south-west (where it amounts to more than $4.0^{\circ} \mathrm{C}$ ) to north-east (where it does not exceed $2.0{ }^{\circ} \mathrm{C}$ ). The variability of $T_{\max }$ from year to year was generally slightly higher in the eastern part of the analysed area (highest $\sigma=2.3{ }^{\circ} \mathrm{C}$ ) than in the west (lowest $\sigma=1.6{ }^{\circ} \mathrm{C}$ ). In the multi-annual course, the highest mean $T_{\max }$ occurred in winter 1974/1975 (particularly in the northwest), 1989/1990 (in the east), 2006/2007 (in the west) and 2015/2016 (only in Stuttgart) and varied from $3.5^{\circ} \mathrm{C}$ in Suwałki to $9.1^{\circ} \mathrm{C}$ in Köln. In all stations except for Kassel, an increase was observed in $T_{\max }$ in winter that was statistically significant in the south of Germany and in three stations in the north and east of Poland.

Due to the selected method, the total number of warm days was approximate in all stations (averaging 3-4 days in a season). In the multi-annual course, it was characterised by high variability from year to year (the standard deviation amounted to 4-5 days), and the highest number of warm days in the season varied from 15 in Regensburg (2015/16) to 23 in Terespol (1989/90). An increasing tendency in the number of warm days was determined in 38 out of 40 stations (95\%). It was statistically significant in 36 of them. The increase was most intensive in Rostock and Łeba, in the north of the study area ( 0.9 day/10 years), although changes generally occurred somewhat faster in the western part of the analysed area than in the east.

Table 1 shows the basic characteristics of winter warm spells occurrence, including total number of warm spells and their duration, as well as the longest warm spell observed during the study period. Both the number of warm spells and their total duration increased slightly from the west to the east of the study area (Table 1, Fig. 2). The total number of warm spells varied from 13 in Arkona to 23 in Poznań, Płock and Lublin (averaging 3-5 per 10 years). Their total length varied from 49 days in Frankfurt to 90 days in Terespol (they lasted from 3.5 to 4.5 days on average) and, in several Polish stations the total duration in the 50-year period exceeded 80 days.

In the multi-annual course, the highest number of warm spells occurred in the winters 1989/1990, 2006/2007 and 2015/2016, but warm spells occurred at all stations only during 


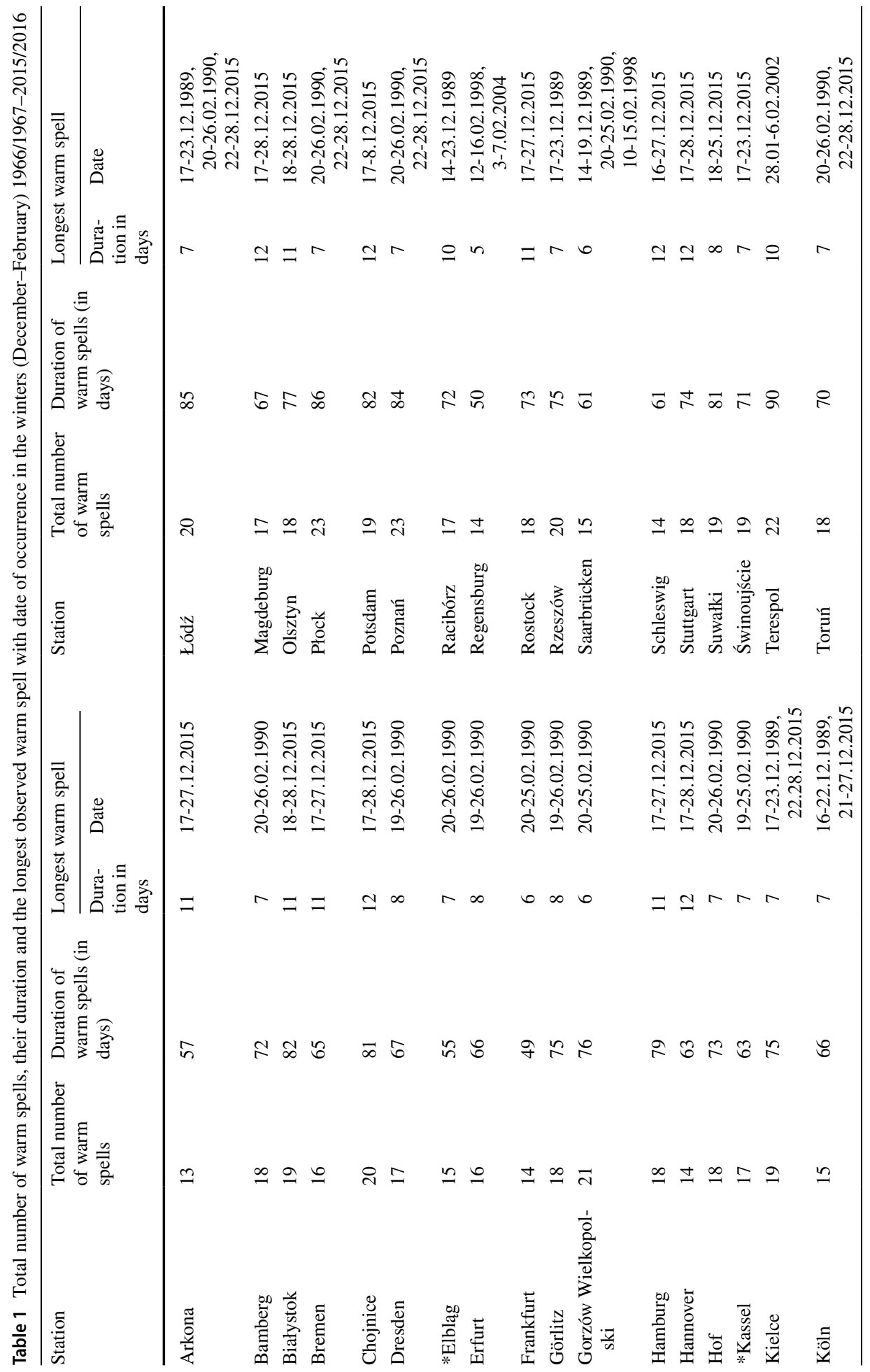




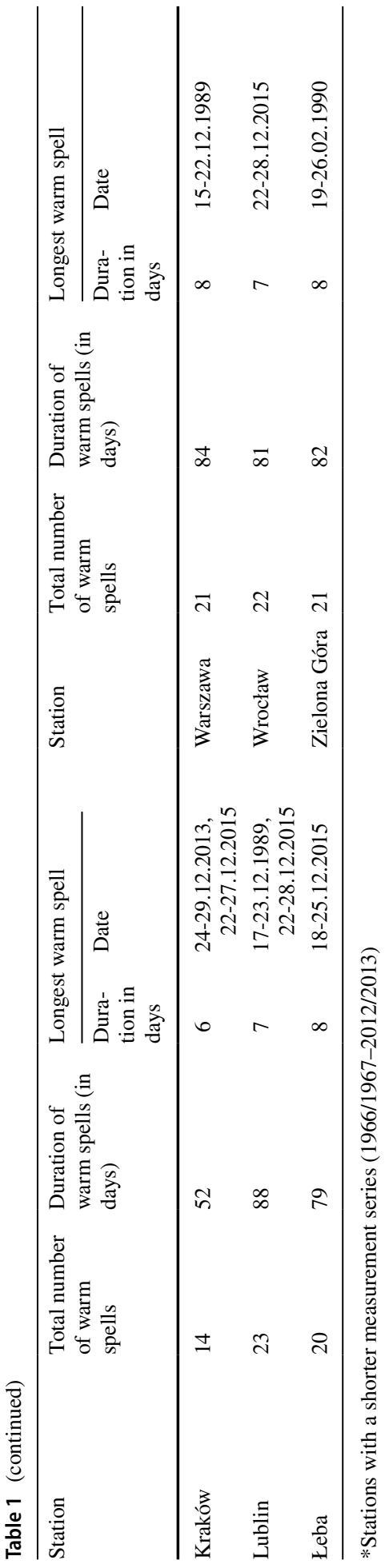




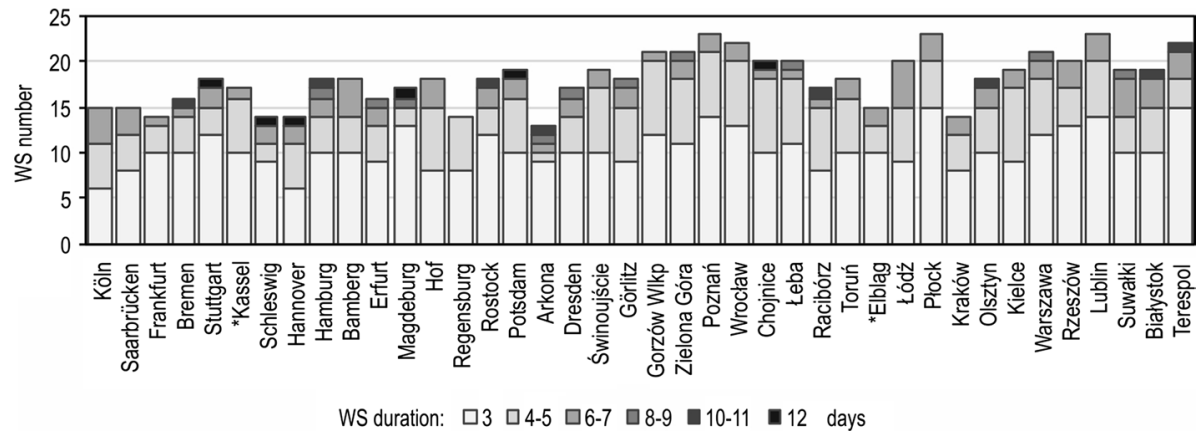

Fig. 2 Number of warm spells (vertical axis) by duration (the legend) in the winters (December-February) 1966/1967-2015/16. *Stations with a shorter measurement series (1966/1967-2012/2013)

the first one, and their number ranged from 2 to 4 for each station. Figure 2 presents the number of warm spells categorised by duration for all stations, ordered from west to east. A somewhat higher frequency of occurrence of warm spells is generally observed in the central and eastern part of the study area in comparison with the western part, but this applies only to longer-lasting warm spells. Warm spells of 3 days occurred most frequently, and they appear equally often in the west and the south of the study area. They constituted from $40 \%$ of all warm spells in Köln to $76 \%$ in Magdeburg (Fig. 2). Warm periods lasting 4-5 days were noted less frequently, and generally they appeared less often in German stations and more often in Polish ones (from $8 \%$ in Arkona to $43 \%$ in Regensburg). Warm spells lasting more than 1 week were rare. The longest lasted for 12 days and occurred in several stations in the northern part of the study area and in Stuttgart in the second half of December 2015 (Table 1). The area covered by this long-lasting warm spell would have been considerably larger and would also have occurred in central Poland if not for the interruption of a 1-day cooling, resulting in two shorter warm spells.

Figure 3 shows the average number of warm spells occurring in each winter month. In the majority of the analysed stations, warm spells usually occurred in December (up to $56 \%$ of all cases in Rostock), and in some stations, particularly in north-western Germany, also in February (up to $57 \%$ of all cases in Hannover; Fig. 3). The number of warm spells

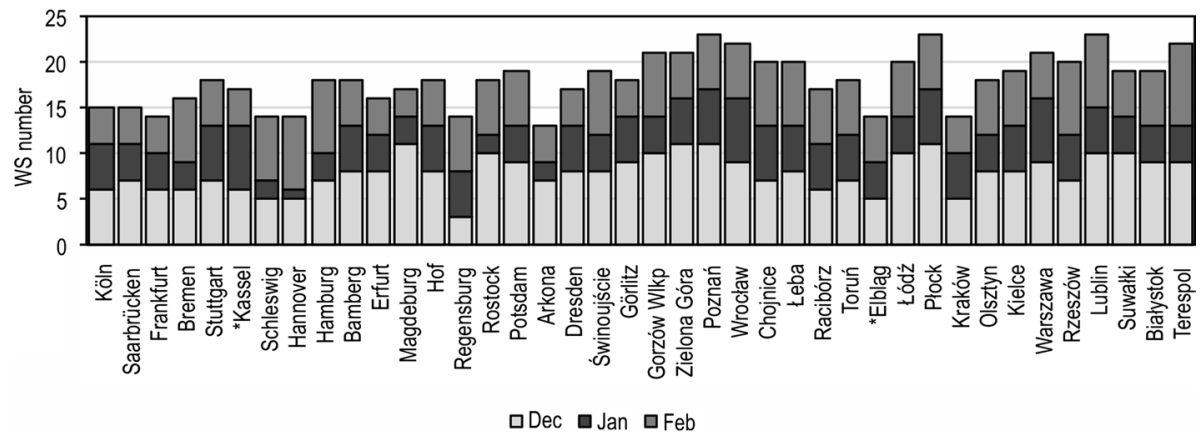

Fig. 3 Number of warm spells (vertical axis) by month of occurrence (see legend) in the winters (December-February) 1966/1967-2015/2016. *Stations with a shorter measurement series (1966/1967-2012/2013) 
in January and February was similar in the majority of stations, although in most of them slightly fewer warm spells were noted in January, being the coldest month. A particularly low contribution of warm spells in January was typical for stations in northern Germany (in Hannover they constituted only $7 \%$ of all cases), while in some western stations the lowest number of warm spells was noted in February (e.g. Stuttgart and Kassel).

Figure 4 shows the highest daily $T_{\max }$ recorded during the analysed warm spells and the date of occurrence. The highest observed daily $T_{\max }$ during warm spells in particular stations varied from $14.4{ }^{\circ} \mathrm{C}$ in Schleswig to $21.0^{\circ} \mathrm{C}$ in Stuttgart (Fig. 4). In 36 out of 40 analysed stations, it occurred during the same warm spell on days from 20 to 25 February 1990. This suggests that it was an exceptionally warm spell with a considerable spatial range.

The analysis of occurrence of warm spells in Central Europe allowed 21 events to be selected, for which a warm spell appeared in least $25 \%$ of stations. These events were considered in the further part of the study.

In the next step, pressure conditions in the troposphere accompanying warm spells in Central Europe were analysed. To this end, anomalies of geopotential heights and of air temperatures for the days of warm spells were computed and contoured in the vertical cross sections of the troposphere (Fig. 5; see Sect. 2 for methodological details). The occurrence of warm spells in winter was related to positive anomalies of geopotential heights on all isobaric levels throughout the troposphere (Fig. 5). In contrast to average conditions in a given multi-annual period, the greatest changes in geopotential height occurred at a level of $250 \mathrm{hPa}$ and exceeded $200 \mathrm{~m}$. The centre of anomalies with deviations exceeding $280 \mathrm{~m}$ was located over the area between 42.5 and $50^{\circ} \mathrm{N}$ and 12.5 and $22.5^{\circ} \mathrm{E}$. In the air column below the centre of positive geopotential anomalies, positive air temperature anomalies

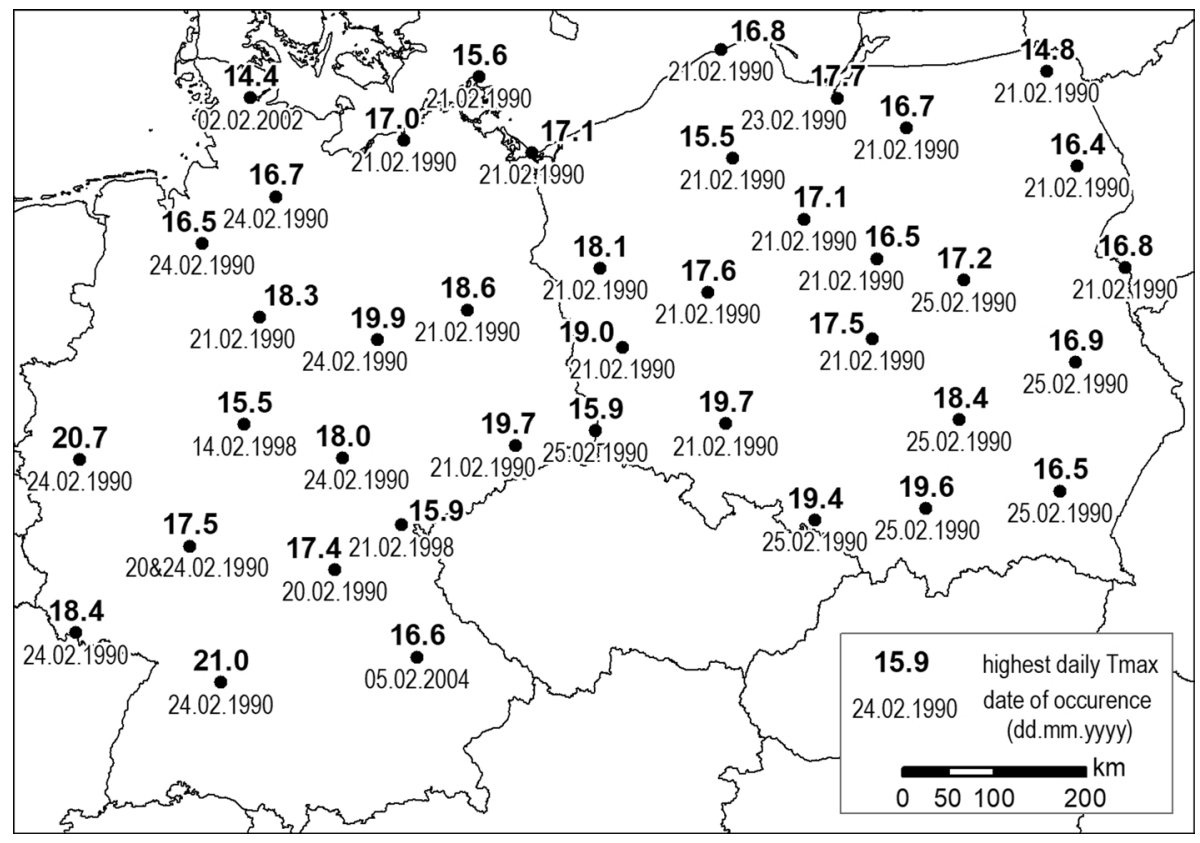

Fig. 4 Highest daily $T_{\max }$ recorded during winter (December-February) warm spells in the winters 1966/1967-2015/2016 with date of occurrence 
(a)

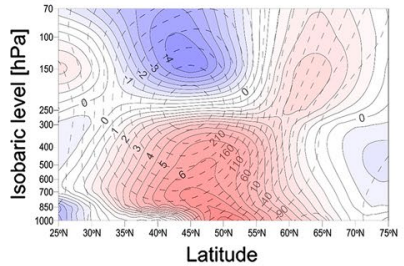

(b)

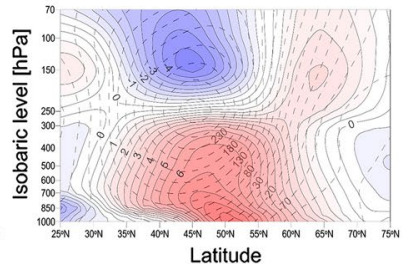

(c)

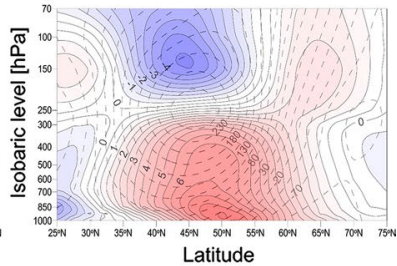

(d)

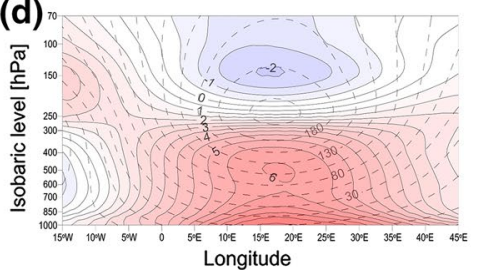

Fig. 5 Mean anomalies of geopotential heights (dashed lines) and of air temperature on the geopotential levels (solid lines and colour shades) in the vertical cross sections of the troposphere along the meridians: $10^{\circ} \mathrm{E}(\mathbf{a}), 15^{\circ} \mathrm{E}(\mathbf{b}), 20^{\circ} \mathrm{E}(\mathbf{c})$ and along the parallel $52.5^{\circ} \mathrm{N}(\mathbf{d})$ computed for all analysed warm spells

occurred with the highest values exceeding $8{ }^{\circ} \mathrm{C}$ on $1000-925 \mathrm{hPa}$ geopotential levels. Positive temperature anomalies covered the area between 40 and $67.5^{\circ} \mathrm{N}$ (maximum $50^{\circ} \mathrm{N}$ ). Shifting upward, the geopotential levels resulted in negative temperature anomalies (up to $-4{ }^{\circ} \mathrm{C}$ ), detected right above the centre of the maximum positive anomalies of geopotential height. The vertical pattern of geopotential height and temperature anomalies reveals the scheme of flow and kinetics within an anticyclonic system. In the upper part of an anticyclone, cold air masses converge, while in its lower parts they subside (i.e. the downward vertical movement of air masses is coupled with their adiabatic heating).

Figure 6 shows the mean composite horizontal pressure and thermal conditions during the winter warm spell in Central Europe. The Euro-Atlantic sector was under the influence of an extensive low-pressure system with a centre over the North Atlantic $(<990 \mathrm{hPa})$ and a strong high with a centre over North Africa (>1028 hPa) (Fig. 6). The aforementioned baric systems were considerably more active than the average in the analysed period, as suggested by the distribution of SLP anomalies. In the centre of the low-pressure system, SLP was $>14 \mathrm{hPa}$ lower than average, and $>8 \mathrm{hPa}$ higher in the high-pressure system. The consequence of such a distribution of SLP was a high level of pressure gradient causing strong advection of air masses from the western sector. On the analysed days, isolines of the $250 \mathrm{hPa}$ isobaric surface over western, southern and central Europe were bent northwards, creating an evident elevation. This suggests the presence of warm air masses. The range of positive anomalies covered a major area of Europe, and their centre was located over the Gulf of Venice $(>270 \mathrm{~m})$. The advection of warm air masses is also suggested by positive anomalies of T850, extending from south-west to north-east from the centre over Central Europe $\left(>7^{\circ} \mathrm{C}\right)$.

Having recognised strong anomalies of z $250 \mathrm{hPa}$ geopotential height, which accompany the occurrence of warm spells in Central Europe, the attempt was made to detect the formation of the anomaly centre in the days preceding warm periods. To this end, composite (for all 21 designated warm spells) anomaly maps of z250 and SLP were constructed for the days preceding warm spells (Fig. 7). On average, the first z250 anomalies began to develop approximately 9 days before the beginning of warm spells over the study area, 
(a)

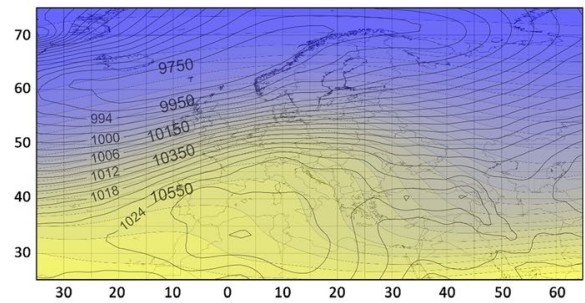

(b)

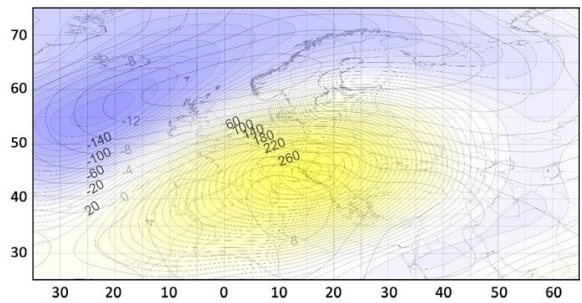

(c)

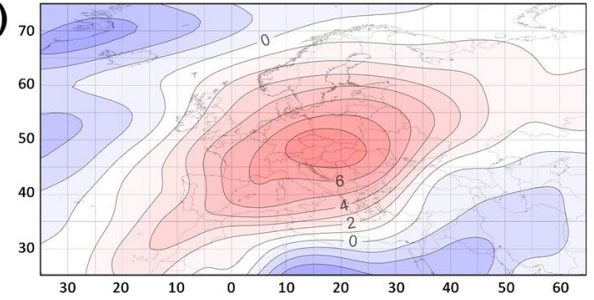

Fig. 6 Average SLP (solid lines) and z250 hPa (colour shades) (a), SLP (solid lines) and z250 hPa (colour shades) anomalies (b), and T850 anomalies (c) during the analysed warm spells in the winters (DecemberFebruary) 1966/67-2015/16

and their centre $(>35 \mathrm{~m})$ was located over the Atlantic west of the Canary Islands. On the subsequent days, the anomalies shifted towards the north-east and strengthened. From around the 7th day, they were already located over the continent, and their range covered the study area. On subsequent days, the centre of anomalies was located over the northern part of the Mediterranean Sea. From the 5th day, anomalies in the centre of the system exceeded $100 \mathrm{~m}$, and $220 \mathrm{~m} 1$ day before the beginning of the warm spell. Simultaneously, over the ocean, an area of negative anomalies was observed, where on the day preceding the beginning of the spell, in the centre, z250 hPa was located $230 \mathrm{~m}$ lower than average. Considerable SLP anomalies were also recorded on the analysed days. The routes of progression of SLP anomaly centres were approximate to the courses of z250 hPa anomaly centres, although at sea level the entire systems were shifted towards the south-west. The situation described above generated advection of warm air masses from the south-west, as confirmed by T850 anomalies moving to the north-east. One day before the beginning of warm spells, positive anomalies covered a major part of the continent, and their centre $\left(>5^{\circ} \mathrm{C}\right)$ was located in the area extending over West Europe.

The above description concerns only the average situation for all analysed warm spells in Central Europe. The routes of progression of centres of z250 hPa anomalies in particular warm spells differed not only in terms of duration, but also in terms of route (Fig. 8). In a large majority of the analysed cases, the beginning of development of anomalies was recorded over the Atlantic Ocean near the Azores. On subsequent days, they moved towards the east and north-east. In the case of two spells (from 1983 and 2015), the source area shifted northwards of the remaining ones. Centres of anomalies in those cases initially moved eastwards and then southwards or to south-west. The warm spell from 2015 was preceded by the progression of two centres of z $250 \mathrm{hPa}$ anomalies from over the ocean; one moved from over the Canary Islands, while the other moved from an area southwest of Iceland. The centres were combined over the continent 2 days before the beginning of the warm spell. In the case of only one warm spell (from 1985) did anomalies 

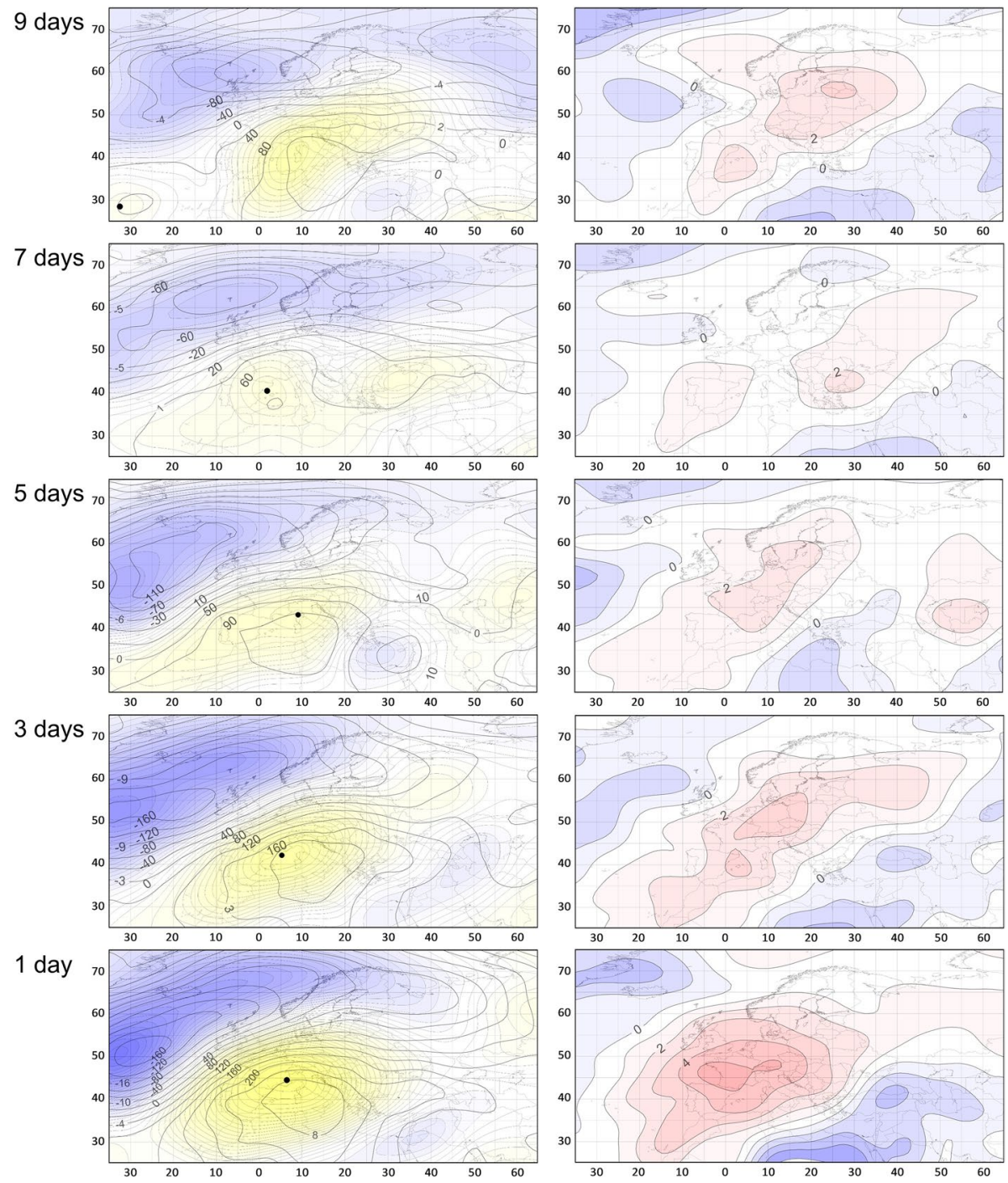

Fig. 7 Average anomalies of z250 hPa (colour shades) and SLP (solid lines) (left column), and average anomalies of T850 (right column), 9 days to 1 day before the beginning of warm spells over Central Europe in the winters (December-February) 1966/1967-2015/2016. Centre of maximum z250 anomalies is marked with a black dot

begin developing outside the area of the Atlantic-when they began over North Africa. The earliest anomalies $(02.1990,2000)$ began developing more than 10 days before the beginning of warm spells, although the routes of progression of the centres were ambiguous. This was the consequence of several days of movement of centres over Central Europe and presence of blocking negative centres of z250 hPa anomalies. Centres of anomalies on the day preceding the beginning of warm spells were located to the west, south-west or south of the study area. In a large majority of the analysed cases, shifting z $250 \mathrm{hPa}$ 
26-29.12.1975

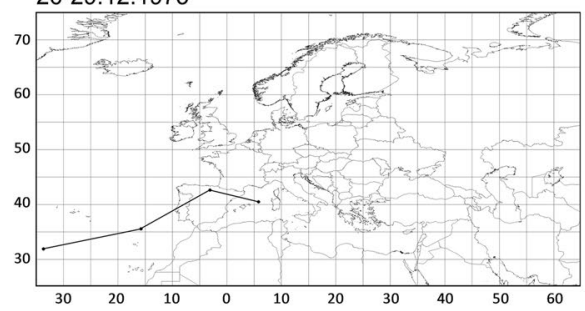

03-06.12.1985

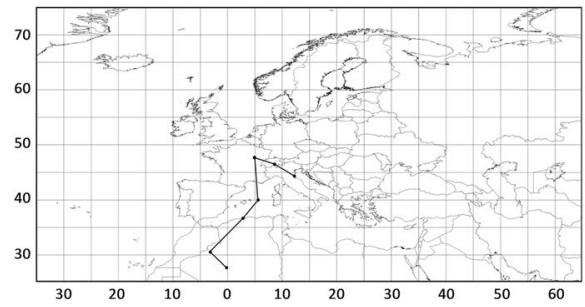

05-09.12.2006

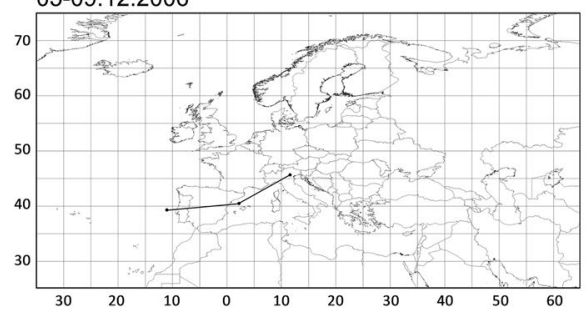

27-29.01.1983

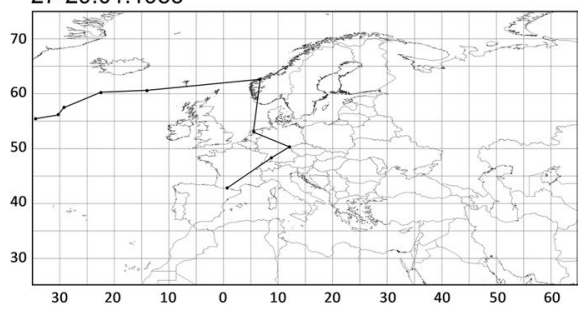

12-16.02.1998

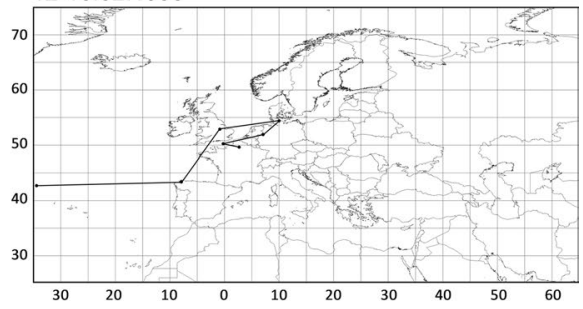

17-27.12.2015

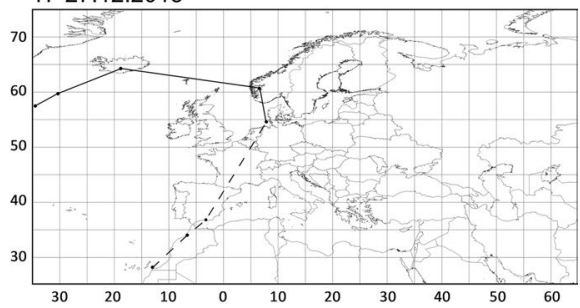

Fig. 8 Routes of z250 hPa anomaly centres during the days preceding the selected warm spells (the first dot marks the beginning of development of $\mathrm{z} 250 \mathrm{hPa}$ anomalies; the last dot marks the position of the $\mathrm{z} 250 \mathrm{hPa}$ anomaly centre in the first day of a warm spell; dates above each map indicate duration of warm spell)

anomalies were strengthened. On the day of development of anomalies, their values varied from $20 \mathrm{~m}$ (1985) to $430 \mathrm{~m}$ (1983). On the day preceding the beginning of a warm spell, their values varied from $140 \mathrm{~m}$ (12.2006) to $480 \mathrm{~m}$ (1998). In the case of four warm spells (27-29.01.1983, 19-26.02.1990, 09-11.01.2007, 18-20.01.2007), during movement, the anomalies were weakened. An important factor influencing the speed and direction of movement of positive z $250 \mathrm{hPa}$ anomalies was the dynamics of the entire z250 hPa field over the study area, and particularly the location and strength of negative $\mathrm{z} 250 \mathrm{hPa}$ anomalies that blocked eastwards propagation of the elevation of the $\mathrm{z} 250 \mathrm{hPa}$ level.

\section{Discussion and summary}

The increase in air temperature in the winter season in Central Europe has been proven in the study, although the observed changes in the majority of the stations were not statistically significant. The obtained results are in accordance with earlier research concerning thermal conditions in winter, the authors of which pointed to a lack of statistically significant changes in many regions of the study area (Kundzewicz and Huang 2010; Wójcik and Miętus 2014; Owczarek and Filipiak 2016). The observed warming translated into an 
increase in the number of warm days in the winter season. In the large majority of stations, the recorded changes were statistically significant, and the greatest increase was observed in the north of the study area.

Numerous studies have shown that the increase in air temperature in winter observed over the recent decades has caused a decrease in the frequency of frosty days and cold spells (Tomczyk 2015; Lhotka and Kyselý 2015; Owczarek and Filipiak 2016). Considerably less attention has been paid to the winter occurrence of exceptionally warm periods, the effects of which concern both the natural environment and human life and economyparticularly the agricultural sector (Menzel et al. 2011). In the upcoming years, further increases in the number of warm days is expected as a result of the ongoing increase in air temperature that may be as much as even $4.7^{\circ} \mathrm{C}$ higher by 2100 (Piniewski et al. 2017).

In the analysed multi-annual period, from 3 to 5 winter warm spells per 10 years have been recorded on average. In the multi-annual course, the highest number of warm spells was characteristic of the 1989/1990, 2006/2007 and 2015/2016 winters. However, only during the 1989/1990 season did warm spells occur in all stations-from 2 to 4 in each of them. During winter 2015/2016, the longest warm spell of 12 days was observed, covering several stations in the northern part of the study area and Stuttgart.

The occurrence of warm spells in winter was related to considerably more active and more intensive baric systems than average in the analysed period, as suggested by the distribution of SLP anomalies. In the centre of the low-pressure system, SLP was lower than average by $>14 \mathrm{hPa}$, and $>8 \mathrm{hPa}$ higher in the high-pressure system. Such a distribution of SLP anomalies suggests intensive advection of air masses from the south-west. This results in positive air temperature anomalies in Europe (Beranová and Huth 2007; Ptak et al. 2018) and intensive melting of snow cover (Bednorz 2002, 2009).

During the occurrence of warm spells over the study area, positive anomalies of geopotential heights were recorded in the cross section of the entire troposphere as a consequence of the presence of warm air masses. The greatest anomalies were recorded at a level of $250 \mathrm{hPa}$. Similar results were obtained for the summer season, analysing selected days in the most intensive hot waves in south-west Europe (Tomczyk et al. 2017). The occurrence of strong anomalies of geopotential heights in the upper troposphere was also observed during the occurrence of heat and cold waves in China (Qian et al. 2016; Chen et al. 2017). The presence of warm air masses is evidently confirmed by air temperature anomalies with the highest values recorded at 1000-925 hPa geopotential levels. Warm air masses covered a major part of the continent; the maximum positive temperature anomalies were observed over Central Europe $\left(>7^{\circ} \mathrm{C}\right)$.

The occurrence of positive anomalies of air temperature and positive anomalies of geopotential heights right over them complies with the hydrostatic balance in the troposphere. It was evidenced that maximum anomalies of the geopotential height appear in the higher troposphere and can be detected from several to even more than 10 days prior to the occurrence of surface temperature extremes. Similar results were obtained by Qian and Jiang (2014), Qian et al. (2016) and Chen et al. (2017), who proved that heat waves and cold surges in China are preluded by disturbances in the higher troposphere (namely anomalies of geopotential heights), which can appear even more than 20 days prior to the surface temperature extremes.

According to this study, anomalies of $250 \mathrm{hPa}$ geopotential height developed on average 9 days before the beginning of warm spells in Central Europe. Detailed analysis covered 21 winter warm episodes for which centres of maximum z250 hPa anomalies were identified, and back trajectories of their movement were reconstructed. The Azorean region of the Atlantic Ocean was area in which the anomalies most frequently developed, and the course 
of their movement was towards the north-east. The speed and direction of movement of the positive anomalies centres was modified by the dynamics of the entire $\mathrm{z} 250 \mathrm{hPa}$ field over the study area, and particularly by the location and strength of negative $\mathrm{z} 250 \mathrm{hPa}$ anomalies that in some cases blocked eastwards propagation of the elevation of the $\mathrm{z} 250 \mathrm{hPa}$ level. Earlier studies (e.g. Qian et al. 2016) postulated that tracking down the disturbances in higher tropospheric geopotential levels may improve the predictability of surface weather extremes, which is also the conclusion of this study concerning winter warm spells in Central Europe.

Acknowledgements This work was supported by the National Science Centre, Poland (Grant number UMO-2017/24/C/ST10/00109).

Open Access This article is distributed under the terms of the Creative Commons Attribution 4.0 International License (http://creativecommons.org/licenses/by/4.0/), which permits unrestricted use, distribution, and reproduction in any medium, provided you give appropriate credit to the original author(s) and the source, provide a link to the Creative Commons license, and indicate if changes were made.

\section{References}

Bednorz E (2002) Snow cover in western Poland and macro-scale circulation conditions. Int J Climatol 22(5):533-541

Bednorz E (2009) Wpływ sytuacji barycznych na występowanie pokrywy śnieżnej na obszarach nizinnych środkowej Europy (The influence of baric situations on snow cover occurrence in central European lowlands). Wydawnictwo Naukowe Uniwersytetu im. Adama Mickiewicza, Poznan

Beniston M, Stephenson DB (2004) Extreme climatic events and their evolution under changing climatic conditions. Glob Planet Change 44:1-9

Beranová R, Huth R (2007) Time variations of the relationships between the North Atlantic Oscillation and European winter temperature and precipitation. Studia Geophys Geod 51:575-590

Bielec-Bąkowska Z, Piotrowicz K (2013) Temperatury ekstremalne w Polsce w latach 1951-2006 (Extreme temperatures in Poland 1951-2006). Prace Geograficzne 132:59-68

Chen Y, Hu Q, Yang Y, Qian W (2017) Anomaly based analysis of extreme heat waves in Eastern China during 1981-2013. Int J Climatol 37:509-523

Chmielewski FM, Muller A, Bruns E (2004) Climate changes and trends in phenology of fruit trees and field crops in Germany 1961-2000. Agr For Meteorol 121(1-2):69-78

Della-Marta PM, Haylock MR, Luterbacher J, Wanner H (2007) Doubled length of western European summer heat waves since 1880. J Geophys Res 112:D15103

Diffenbaugh NS, Singh D, Mankin JS, Horton DE, Swain DL, Touma D et al (2017) Quantifying the influence of global warming on unprecedented extreme climate events. Proc Natl Acad Sci India A 114(19):4881-4886

Fischer EM, Schär C (2010) Consistent geographical patterns of changes in high-impact European heatwaves. Nat Geosci. https://doi.org/10.1038/ngeo866

Francis JA, Vavrus SJ (2012) Evidence linking Arctic amplification to extreme weather in mid-latitudes. Geophys Res Lett 39:L06801. https://doi.org/10.1029/2012GL051000

IPCC (2013) Climate change: the physical science basis. Contribution of working group I to the fifth assessment report of the intergovernmental panel in climate change. Cambridge University Press, Cambridge

Kalnay E, Kanamistu M, Kistler R, Collins W, Deaven D, Gandin L, Iredell M, Saha S, White G, Woollen J, Zhu Y, Leetmaa A, Reynolds R, Chelliah M, Ebisuzaki W, Higgins W, Janowiak J, Mo KC, Ropelewski C, Wang J, Jenne R, Joseph D (1996) The NMC/NCAR 40-year reanalysis project. Bull Am Meteorol Soc 77:437-471

Katz RW, Brown RR (1992) Extreme events in a changing climate: variability is more important than averages. Clim Change 21:289-302

Klein Tank AMG, Winjgaard JB, Können GP, Böhm R, Demarée G, Gocheva A, Mileta M, Pashiardis S, Hejkrlik L, Kern-Hansen C, Heino R, Bessemoulin P, Müller-Westermeier G, Tzanakou M, Szalai S, Pálsdóttir T, Fitzgerald D, Rubin S, Capaldo M, Maugeri M, Leitass A, Bukantis A, Aberfeld R, van Engelen AFV, Forland E, Mietus M, Coelho F, Mares C, Razuvaev V, Nieplova E, Cegnar T, Antonio López J, Dahlström B, Moberg A, Kirchhofer W, Ceylan A, Pachaliuk O, Alexander LV, Petrovic P 
(2002) Daily dataset of 20th-century surface air temperature and precipitation series for the European Climate Assessment. Int J Climatol 22(12):1441-1453

Kundzewicz ZW, Huang S (2010) Seasonal temperature extremes in Potsdam. Acta Geophys 58(6):1115-1133

Lhotka O, Kyselý J (2015) Characterizing joint effects of spatial extent, temperature magnitude and duration of heat waves and cold spells over Central Europe. Int J Climatol 35(7):1232-1244

Luterbacher J, Liniger MA, Menzel A, Estrella N, Della-Marta PM, Pfister C, Rutishauser T, Xoplaki E (2007) The exceptional European warmth of autumn 2006 and winter 2007: historical context, the underlying dynamics and its phenological impacts. Geophys Res Lett 34:L12704. https://doi.org/10.1029/2007GL029951

Menzel A, Seifert H, Estrella N (2011) Effects of recent warm and cold spells on European plant phenology. Int J Biometeorol 55(6):921-932

Nairn JR, Fawcett RJ (2011) Defining heatwaves: heatwave defined as a heat-impact event servicing all community and business sectors in Australia. CAWCR technical report No. 060, The Centre for Australian Weather and Climate Research, Australia

Owczarek M, Filipiak J (2016) Contemporary changes of thermal conditions in Poland, 1951-2015. Bull Geographys Phys Geogr Ser 10:31-50

Perkins SE (2015) A review on the scientific understanding of heatwaves-their measurement, driving mechanisms, and changes at the global scale. Atmos Res 164:242-267

Perkins SE, Alexander LV (2013) On the measurement of heat waves. J Clim 26(13):4500-4517

Perkins SE, Alexander LV, Nairn JR (2012) Increasing frequency, intensity and duration of observed global heatwaves and warm spells. Geophys Res Lett 39:L20714

Peterson TC, Heim JRRR, Hirsch R, Kaiser DP, Brooks H, Diffenbaugh NS, Dole MD, Giovannettone JP, Gurguis K, Karl TR, Katz RW, Kunkel K, Enmaier DL, Mccabe GJ, Paciorek CJ, Ryberg KR, Schubert S, Silva VBS, Stewart BC, Vecchia AV, Villarini G, Vose RS, Walsh J, Wehner M, Wolock D, Wolter K, Woodhouse CA, Wuebbles D (2013) Monitoring and understanding changes in heat waves, cold waves, floods, and droughts in the United States: state of knowledge. Bull Am Meteorol Soc 94(6):821-834

Piniewski M, Mezghani A, Szcześniak M, Kundzewicz Z (2017) Regional projections of temperature and precipitation changes: robustness and uncertainty aspects. Meteorol Z 26:223-234

Ptak M, Tomczyk AM, Wrzesiński D (2018) Effect of teleconnection patterns on changes in water temperature in Polish Lakes. Atmosphere 9:66. https://doi.org/10.3390/atmos9020066

Qian WH, Jiang M (2014) Early signals of synoptic-scale atmospheric anomalies associated with the summer low temperature events in Northeast China. Meteorol Atmos Phys 124:33-46

Qian WH, Yu TT, Du J (2016) A unified approach to trace surface heat and cold events by using height anomaly. Clim Dyn 46(5):1647-1664

Shabbar A, Bonsal B (2003) An assessment of changes in winter cold and warm spells over Canada. Nat Hazards 29(2):173-188

Shevchenko O, Lee H, Snizhko S, Mayer H (2014) Long-term analysis of heat waves in Ukraine. Int J Climatol 34:1642-1650

Smith TT, Zaitchik BF, Gohlke JM (2013) Heat waves in the United States: definitions, patterns and trends. Clim Change 118(3-4):811-825

Tomczyk AM (2015) Impact of macro-scale circulation types on the occurrence of frosty days in Poland. Bull Geogr Phys Geogr Ser 9:55-65

Tomczyk AM, Półrolniczak M, Bednorz E (2017) Circulation conditions' effect on the occurrence of heat waves in Western and Southwestern Europe. Atmosphere 8:31. https://doi.org/10.3390/atmos8020031

Ummenhofer CC, Meehl GA (2017) Extreme weather and climate events with ecological relevance: a review. Philos Trans R Soc B 372:20160135

Wibig J (2007) Fale ciepła i chłodu w środkowej Polsce na przykładzie Łodzi (Waves of warmth and coldness in Central Poland on the example of Łódź). Acta Univ Lod Folia Geogr Phys 8:27-61

Wibig J, Podstawczyńska A, Rrzepa M, Piotrowski P (2009) Heatwaves in Poland- frequency, trends and relationships with atmospheric circulation. Geographia Polonica 81(1):33-46

Wójcik R, Miętus M (2014) Niektóre cechy wieloletniej zmienności temperatury powietrza w Polsce (19512010) (Some features of long-term variability in air temperature in Poland (1951-2010)). Przegląd Geograficzny 86(3):339-364

You Q, Jiang Z, Kong L, Wu Z, Bao Y, Kang S, Pepin N (2017) A comparison of heat wave climatologies and trends in China based on multiple definitions. Clim Dyn 48(11-12):3975-3989

Publisher's Note Springer Nature remains neutral with regard to jurisdictional claims in published maps and institutional affiliations. 